\title{
The Constitution as a Code of Honor
}

by Peter Shane_http://washingtonmonthly.com/people/peter-shane/)

April 4, 2016 12:15 PM

LAW AND JUSTICE

It would probably delight the late Justice Antonin Scalia to know that the fight over his successor was generating constitutional controversy. Indeed, like many controversies that Justice Scalia fueled, this one concerns not only the implications of particular clauses, but the very nature of constitutional law.

In nominating Judge Merrick B. Garland to succeed Justice Scalia, President Obama declared: "As President, it is . . . my constitutional duty to nominate a Justice. . . I hope that our Senators will do their jobs, and move quickly to consider my nominee. That is what the Constitution dictates....”

The President's rhetoric of duty and obligation, however, quickly elicited dissents. Noah Feldman writes: "II]f Obama didn't want to nominate a replacement for Justice Antonin Scalia at all, it would be within his constitutional discretion not to do so." As to the Senate, Jonathan Adler argues: "The Senate may withhold its consent by voting down a nominee, but it may also withhold its consent by refusing to act, or otherwise failing to confirm a nominee." These two esteemed legal scholars with very different politics are hardly alone in their views.

The arguments for the "not-a-duty" position are typically based on the sorts of textual and historical arguments Justice Scalia advocated. Article II declares that the President "by and with the advice and consent of the Senate, shall appoint ... judges of the Supreme Court." But "shall" in legal instruments does not always mean "must." As for the Senate, "Each House [of Congress] may determine the Rules of its proceedings." Such blanket language on its face supports the idea that the Senate has the discretion to proceed with nominees quickly or slowly, with much or little debate, or, indeed, not at all.

Lost in the fog, however, is an idea of the Constitution that Justice Scalia no doubt regarded as "arglebargle," but which is both historically and in principle a stronger and more appealing concept than his own. It is the view that Chief Justice John Marshall elaborated in the famous 1819 case upholding the constitutionality of the National Bank of the United States, McCulloch v. Maryland. 
The Constitution, Marshall argued, should be interpreted in light of its peculiar nature and overarching purposes. The "nature" of the Constitution, according to Marshall, "requires that only its great outlines should be marked, its important objects designated, and the minor ingredients which compose those objects be deduced from the nature of the objects themselves." The Constitution was "intended to endure for ages to come, and consequently to be adapted to the various crises of human affairs." The propriety of congressional action, he said, must "consist with the letter and spirit of the Constitution." This is "living Constitution" language. "Spirit of the Constitution" is not a phrase one would associate with Justice Scalia. It would have been more congenial to Chief Justice Charles Evan Hughes, who expressed a similar thought thusly: "Behind the words of the constitutional provisions are postulates which limit and control."

With regard to Supreme Court appointments, the spirit of the Constitution emanates conspicuously from three sources. One is the design of government itself. Having three co-equal federal branches is one of the Constitution's two foundational design features, the other being federalism. The Supreme Court is the one constitutionally mandated judicial institution. Constitutionally, there must be a Supreme Court, and it should be a Supreme Court able to effectively and efficiently accomplish its constitutionally imperative tasks - pursuing uniformity in the interpretation of federal law and enforcing the Constitution's limitations on government action. Thus, the spirit of the Constitution casts a shadow of potential illegitimacy over any branch's initiative that would foreseeably weaken the Supreme Court.

A second consideration, closely related to the first, is the importance in a separation of powers system of forbearance in the exercise of power. James Madison wrote in The Federalist that "none of [the three branches] ought to possess, directly or indirectly, an overruling influence over the others in the administration of their respective powers." Yet each branch, if it exercises its discretionary powers to the fullest, could bring the others to a halt. Only a norm of at least minimal mutual accommodation stands in the way. In refusing even to consider a Supreme Court nominee, the Senate, effectively overruling the President's power of appointment, is breaching that norm.

Finally, the Senate, in categorically hamstringing the President on entirely political grounds, is assuming a role in the appointments process that was never intended. The Constitution explicitly provides that the President take the leading role in staffing the judiciary and executive branch. The anxiety that produced the Senate's role in the appointments process was not policy, but potential corruption. As Alexander Hamilton elaborated, the confirmation requirement was intended as "an excellent check upon a spirit of favoritism in the President, [which] would tend greatly to prevent the appointment of unfit characters from State prejudice, from family connection, from personal attachment, or from a view to popularity." 
History has approved the Senate's weighing of a wider range of factors in judging a specific nominee's merits. But the central point still holds - the Senate is to judge the worthiness of nominees as individuals, not to shut down deliberations altogether.

Of course, none of these considerations establishes a "duty," if, by "duty," one means an obligation enforceable at law. No court will ever enjoin a recalcitrant President to make a nomination or an obstructionist Senate to meet with, deliberate over, or vote on a presidential nominee to the Supreme Court or anything else.

But the Constitution implies a broader view of governmental duty. Article V of the Constitution requires all government officers, both state and federal - including Members of the Senate - to "be bound by Oath or Affirmation, to support [the] Constitution." The President, yet more emphatically, is required to swear or affirm to "faithfully execute" the presidential office and to "preserve, protect and defend the Constitution." Promises to "preserve, protect and defend" - even to "support" - the Constitution plainly commit officeholders to do something more than merely "observe" or "formally comply with" the Constitution. To "support" is to "enable to function," or, as James Madison wrote, to help "in giving effect to the federal Constitution." Should presidents or legislators work to undermine each other's constitutionally assigned functions or to undermine the efficacy of the Supreme Court, it is hard to see how they are not violating their respective oaths. A promise is not much of a promise unless one is obliged, at least as a matter of honor, to keep it.

For this reason, I dissent from a view Benjamin Wittes and Miguel Estrada have expressed pithily and with obvious regret: "Whatever elevated rhetoric anyone invokes to suit his or her convenience, the fact is that our real judicial nominations system is now one of raw power and nothing else." The fact that so few historical precedents exist for refusing consideration and that none is more recent than 1866 suggests that generations of Senators have internalized their constitutional job description even as political and legal contexts have shifted from decade to decade. As long as the rhetoric of honor is still in play, we can still hope that the rawness of power will be tamed by the sense of obligation.

“\#Doyourjob” really means “\#Doyourduty.” 
Peter Shane teaches constitutional law at the Ohio State University's Moritz College of Law and is the author of

Madison's Nightmare: How Executive Power Threatens American Democracy _http://www.amazon.com/madisonsnightmare-executive-threatens-democracy/dp/0226749398)

(University of Chicago Press 2009). 